PP. $78-86$

\title{
UJI POLIMORPIK DAN HETEROZIGOSITAS PADA PROGENI F4 KEDELAI (Glycine max (L.) Merril) TAHAN SALIN DENGAN MENGGUNAKAN MARKA SSR (Simple Sequence Repeats)
}

\author{
Evi Julianita Harahap ${ }^{1 *}$, Rosmayati ${ }^{2}$, dan Diana Sofia Hanafiah ${ }^{2}$ \\ ${ }^{1}$ Program Studi Agroteknologi Fakultas Pertanian Universitas Teuku Umar, Meulaboh \\ ${ }^{2}$ Program Studi Agroteknologi Fakultas Pertanian Universitas Sumatera Utara, Medan \\ *Email: julianitaharahap.evi@gmail.com
}

\begin{abstract}
SSR marker has some merits such as quickness, simplicity, rich polymorphism and stability, thus being widely applied in genetic diversity analysis, molecular map construction and gene mapping. the purpose of this study was to determine polymorpic test and heterozygosity in F4 soybean (Glycine max (L.) Merril) progeni saline resistant characters using SSR (Simple Sequence Repeats) markers. This research was conducted in Biomolecular Laboratory, Socfindo Seed Production Laboratory (SSPL), Kebun Bangun Bandar Village Martebing District Dolok Masihul Regency Serdang Bedagai on December-May 2017. The number of samples were used 44. The five SSR primers (QS080465, QS1101, QS1112, QS100011, and Sat_091) used were specific primers, with a band pattern that was clearly visible around one or two bands. The percentage of polymorphic primers (PLP) of these three populations is high, all populations with a PLP of $100 \%$ of the saline resistant character. The effective allele number $(\mathrm{Ne})$ of 7,160 for the progeny population is lower than the number of observed alleles $(\mathrm{Na})$ of 10,000 which means that many progeny individuals are homozygous. The expected heterozygosity $(\mathrm{He})$ value of 0.854 in the progeny population was higher than the observed heterozygosity (Ho) value of 0.027 . The overall average observed heterozygosity (Ho) was 0.009 lower than the overall expected heterozygosity $(\mathrm{He})$ of 0.61 . This means that each character has a low heterozygosity.
\end{abstract}

Keywords: Progeny F4, soybean, SSR, saline resistant, polymorphic, heterozygosity

\section{PENDAHULUAN}

Usaha peningkatan produksi kedelai saat ini menghadapi kendala berupa penurunan areal tanam dan penyusutan lahan subur akibat alih fungsi lahan ke sektor non pertanian. Optimalisasi penyediaan kedelai dalam negeri berpeluang diarahkan ke lahan suboptimal, di antaranya lahan salin. Salah satu strategi untuk mengatasi dan mengeliminasi penurunan produksi kedelai adalah merakit varietas toleran salinitas. Keberhasilan perakitan varietas kedelai toleran salinitas ditentukan oleh tersedianya sumber gen toleran, yang dapat diperoleh melalui identifikasi terhadap koleksi plasma nutfah kedelai (Krisnawati dan Adie, 2009).

Proses seleksi dan uji lapang untuk karakter morfologi secara umum telah digunakan oleh pemulia 
tanaman untuk mendeskripsikan varietas, akan tetapi memerlukan waktu yang cukup lama dan kebanyakan karater yang nampak merupakan interaksi genetik dan kondisi lingkungan (Jianhua et al., 1996). Melalui penerapan strategi pemuliaan yang memadukan pendekatan biologi molekuler dapat diidentifikasi sifat-sifat penting yang akan dimuliakan pada tingkat DNA. Analisis molekuler sangat dibutuhkan untuk membantu proses seleksi tanaman secara lebih cepat dan akurat. Pemakaian penanda molekuler diharapkan dapat meningkatkan ketepatan proses seleksi serta meningkatkan efisiensi waktu seleksi (Maftuchah, 2005). Pada generasi F4 keragaman genetik non aditif belum dapat mereduksi, khususnya gen overdominansi, dari dalam keragaman fenotipe. Akibatnya adalah seleksi yang dilakukan cenderung mempertahankan famili-famili dengan keragaan terbaik yang didominasi oleh genotipe-genotipe heterozigot pada lokus-lokus yang mengendalikan keragaman tersebut. Genotipe homozigot dominan berkisar $43,7 \%$, homozigot resesif berkisar $43,7 \%$, dan heterozigot berkisar 6,5\% (Dasumiati, 2003).

Mikrosatelit, yang juga dikenal dengan simple sequence repeats (SSR) merupakan DNA berulang yang sub unitnya terdiri atas 1-6 nukleotida. Marka mikrosatelit merupakan marka DNA yang memiliki beberapa keunggulan, yaitu: sangat polimorfis, jumlahnya melimpah, pewarisannya bersifat kodominan, analisisnya sederhana dan mudah ditranfer melalui publikasi sekuen. Sebagai marka kodominan yang lokus spesifik, marka SSR secara luas telah digunakan sebagai penanda untuk identifikasi genotipe dan kajian genetika populasi pada tanaman (Singh et al., 2007).

\begin{tabular}{lcr}
\multicolumn{1}{r}{ Adanya } & variasi & jumlah \\
pengulangan & dari & sekuens \\
mikrosatelit & \multicolumn{2}{c}{ menyebabkan } \\
mikrosatelit & bersifat & sangat \\
polimorfik & sehingga & penanda
\end{tabular}
mikrosatelit sesuai digunakan dalam mempelajari keragaman genetik suatu populasi dan parental analysis (Maftuchah, 2005). Guan et al. (2014) melakukan penelitian validasi beberapa kultivar kedelai yang tahan salinitas dengan marka SSR. Penelitiannya menggunakan 5 marka SSR yaitu QS08064, QS080465, QS1101, QS1112, dan QS100011. Hasil penelitian tersebut menunjukkan bahwa penanda QS080465 menunjukkan bahwa 33 genotipe toleran salinitas. Penanda ini menunjukkan efisiensi seleksi sebesar $94,3 \%$.

Pada penjelasan di atas, Peneliti tertarik melakukan penelitian tentang Uji Polimorpik dan Heterozigositas Pada Genetik Progeni F4 Kedelai (Glycine $\max$ (L.) Merril) Tahan Salin dengan menggunakan Marka SSR (Simple Sequence Repeats).

\section{METODE}

Tempat dan Waktu

Penelitian marka molekuler dilaksanakan di Laboratorium Biomolekuler, Socfindo Seed Production Laboratory (SSPL), Kebun Bangun Bandar Desa Martebing Kecamatan Dolok Masihul Kabupaten Serdang Bedagai. Penelitian ini dilaksanakan 
pada bulan Desember 2016 sampai dengan Mei 2017.

Bahan dan Alat

Penelitian ini menggunakan akar kedelai progeni F4 hasil persilangan tetua betina (Varietas Grobogan (G)) dengan tetua jantan genotipe tahan salin (N5). Bahanbahan yang digunakan dalam penelitian ini antara lain nitrogen cair, PVPP, CTAB, EDTA, Tris$\mathrm{HCl}, \mathrm{NaCl}$, aquades steril, buffer TAE, chloroform:isoamilakohol (KIAA) dengan perbandingan $24: 1$, $\mathrm{NaOH}, \quad \mathrm{CH}_{3} \mathrm{COONa}, \quad \mathrm{CH}_{3} \mathrm{COOH}$ glasial, isopropanol dingin, ethanol $70 \%$, ethanol absolute, agarose, Green PCR master mix, leader DNA, gel red, loading dye, alkohol, ethidium bromide, 5 primer marka mikrosatelit yaitu QS080465, QS1101, QS1112, QS100011 (Guan et al., 2014) dan Sat_091 (Abel, 1969), parafilm, aluminium foil, dan bahan lainnya yang mendukung penelitian ini. Alat yang digunakan dalam penelitian di Laboratorium adalah mortar, alu, centrifuge (eppendorf 5415), spektrofotometer nanodrop, kulkas, vortex, frezer, tabung mikro (ukuran $2 \mathrm{ml}$ dan 0,2 $\mathrm{ml}$ ), pipet mikro (ukuran 1-50 $\mu \mathrm{l}$, 100-500 $\mu \mathrm{l}$, dan 200-1000 $\mu \mathrm{l}$ ), sarung tangan karet, tip pipet mikro (warna putih, kuning, dan biru), rak tabung mikro, rak tip pipet mikro, rak pipet mikro, autoklaf, pemanas (water bath), oven, $\mathrm{pH}$ meter, pengaduk magnetik, sendok spatula, alat-alat gelas (gelas ukur, beaker glass, erlenmeyer), UVtransilluminator (UV Tec Cambridge 20 UV), elektroforesis (Power PAC 3000, BIO RAD), PCR, Gel-Doc (U Cambridge), power supply, masker, sarung tangan, alat tulis dan alat lainnya yang mendukung penelitian ini.

Pelaksanaan Penelitian

Ekstraksi DNA

Isolasi DNA diambil dari akar setelah panen sebanyak 40 progeni F4 kedelai, 2 tetua jantan dan 2 tetua betina dengan total 44 sampel. Prosedur isolasi DNA dari metode CTAB oleh Orozco-Castilo et al. (1994) yang telah dimodifikasi. Pengujian kuantitas DNA dilakukan menggunakan nanophotometer pada panjang gelombang $(\lambda) 260 \mathrm{~nm}$ dan $280 \mathrm{~nm}$ dengan menggunakan $2 \mu \mathrm{l}$ DNA total hasil isolasi dan pemurnian. Kualitas DNA diuji menggunakan agarose $2 \%$, dibuat dengan cara ditimbang 1,6 gr agarose. Lalu dimasukkan ke dalam erlenmeyer ukuran $100 \mathrm{ml}$. Ditambahkan $80 \mathrm{ml}$ TAE 1x dan dipanaskan ke dalam microwave dengan suhu medium selama 2 menit. Kemudian diangkat dan ditambahkan pewarna gelred ethidum bromide $0,5 \mu \mathrm{l}$ lalu kocok perlahan hingga homogen.

PCR dan Elektroforesis

Amplifikasi produk PCR dengan menggunakan 5 marka SSR yaitu QS080465, QS1101, QS1112, QS100011 dan Sat_091 dijalankan berdasarkan penelitian oleh Guan et al. (2014) yang telah dimodifikasi. Program amplifikasi terdiri atas siklus predenaturasi 4 menit pada suhu $95^{\circ} \mathrm{C}$ selama 10 menit, 35 siklus denaturasi $94^{\circ} \mathrm{C}$ selama 30 detik, 35 siklus annealing $55^{\circ} \mathrm{C}$ selama 1 menit 15 detik, 35 siklus elongasi $72^{\circ} \mathrm{C}$ selama 1 menit 30 detik, dan siklus final extension $72^{\circ} \mathrm{C}$ selama 30 menit, dan inkubasi PCR $4^{0} \mathrm{C}$. 
Elektroforesis hasil amplifikasi PCR dilakukan pada gel agarose $1,5 \%$. Gel dibuat dengan melarutkan 0,9 gr agarose dan ditambahkan $60 \mathrm{ml}$ TAE 1x, lalu dipanaskan ke dalam microwave dengan suhu medium selama 2 menit. Kemudian diangkat dan ditambahkan pewarna gelred ethidum bromide $0,5 \mu \mathrm{l}$ lalu kocok perlahan hingga homogen. Elektroforesis dijalankan dengan 50 watt yang dialiri tegangan listrik 110 volt dan $25 \mathrm{~mA}$ selama 30 menit. Hasil elektroforesis diamati dan didokumentasi dengan UVtransilluminator (UV Doc-its) dan Gel-Doc (U Doc-its).

Analisis Data Marka SSR

Analisa data berdasarkan hasil skoring pola pita DNA yang muncul pada gel agarose. Pita diskor dalam bentuk data biner dengan ada pita (1) atau tidak ada (0) pita dengan menggunakan software add-ins excel GenAlex ver.6.501 (Peakall and Smouse, 2012).

\section{HASIL DAN PEMBAHASAN}

Amplifikasi DNA Progeni F4 dengan Marka SSR

Amplifikasi DNA pada 3 populasi F4 kedelai untuk identifikasi karakter tahan salin ini dilakukan menggunakan 5 primer SSR antara lain QS080465, QS1101, QS1112, QS100011, dan Sat_091. Primer SSR merupakan salah satu jenis marka molekuler yang dapat mengidentifikasi keberadaan alel pada suatu genom tanaman. Kelima primer yang digunakan termasuk primer spesifik, dengan pola pita yang tampak jelas sekitar satu atau dua pita saja yang ditunjukkan pada gambar 1.

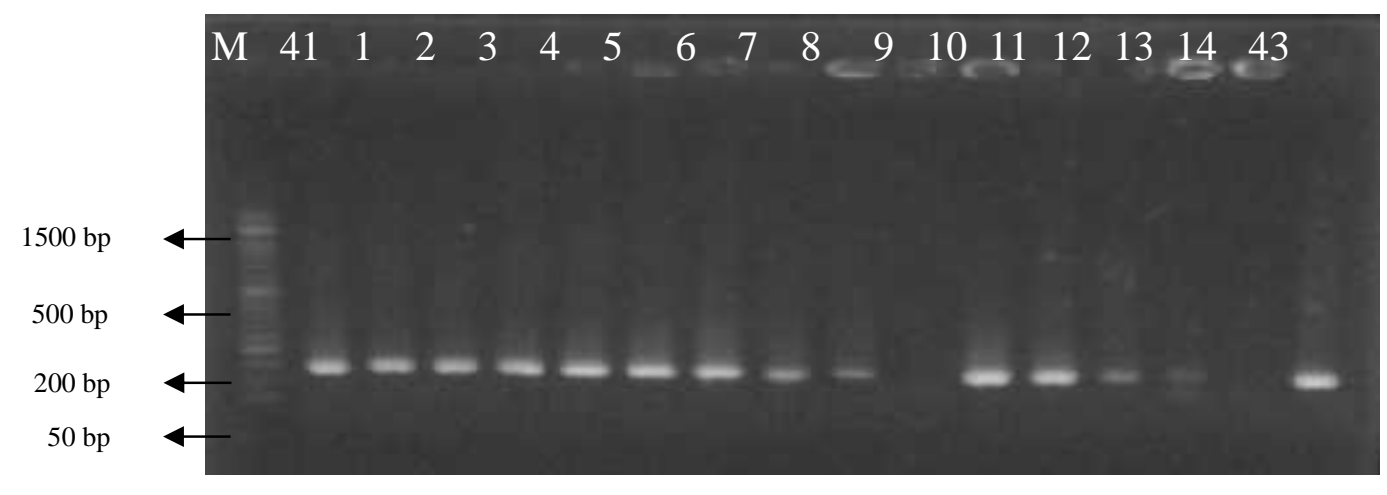

(a)

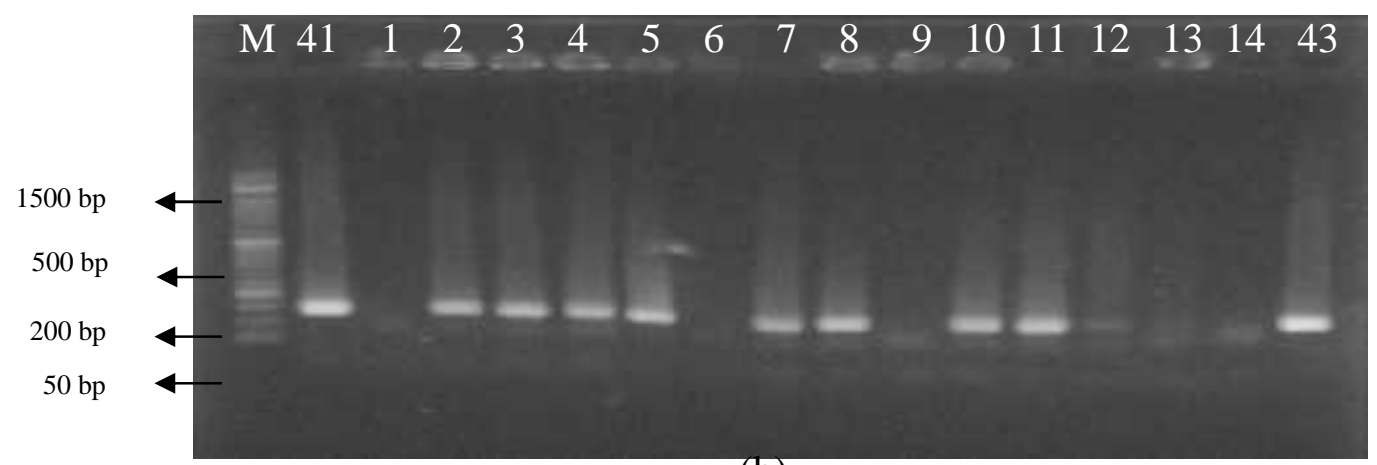

(b) 


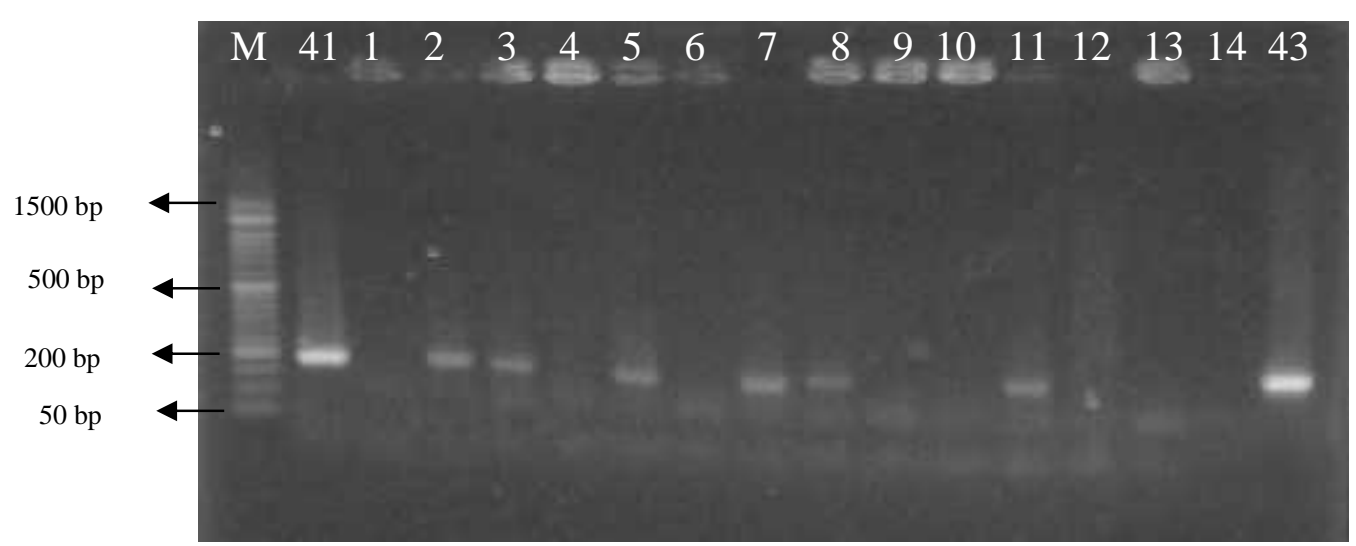

(c)

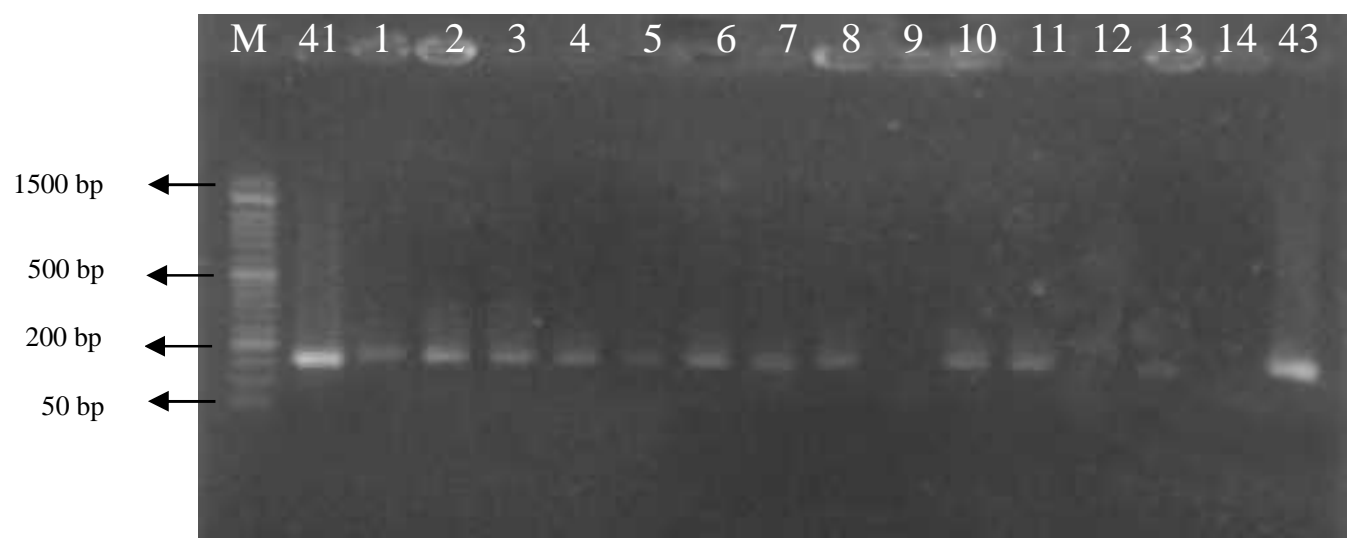

(d)

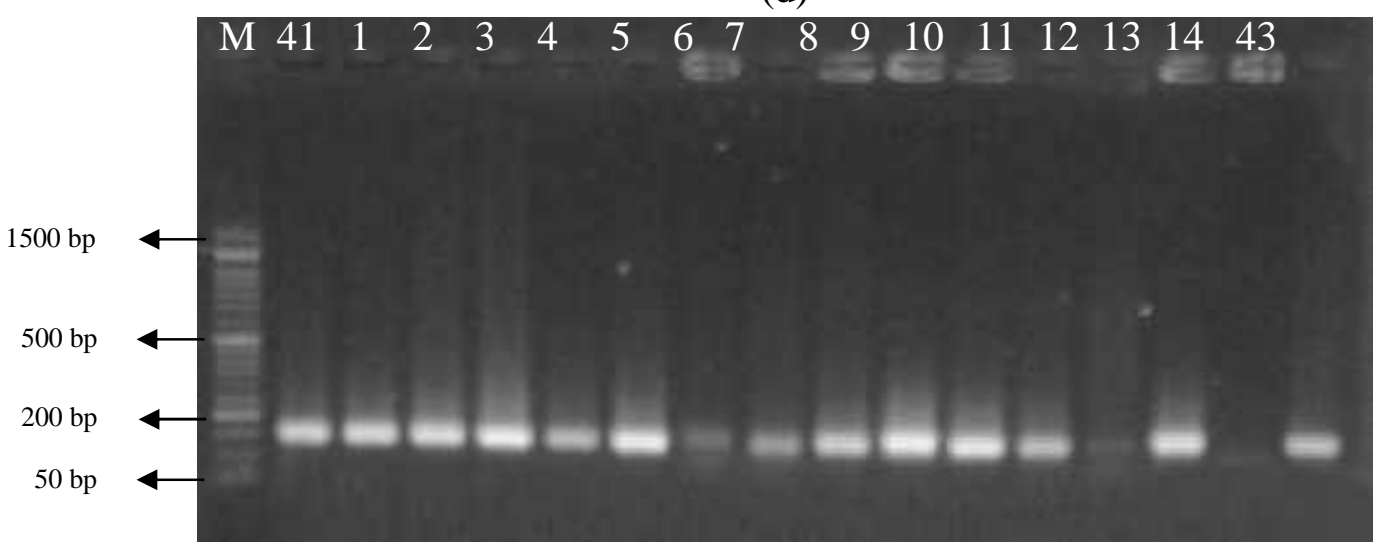

(e)

Gambar 1. Pola Polimorfik Marka SSR progeni F4 kedelai tahan salin dengan primer polimorfik (a ) Pola pita marka QS080465; (b) Pola pita marka QS1101; (c) Pola pita marka QS1112; (d) Pola pita marka QS100011; (e) Pola pita marka Sat_091

Persentase primer polimorfik (PLP) dari ketiga populasi ini termasuk tinggi, semua populasi dengan PLP sebesar $100 \%$ terhadap 
karakter tahan salin. Hasil yang diperoleh menunjukkan bahwa kelima primer yang dievaluasi, semuanya termasuk primer polimorfik terhadap karakter salinitas pada progeni F4 kedelai. Keragaman marka SSR tersebut ditunjukkan oleh ukuran pita yang teramplifikasi pada hasil dokumentasi elektroforesis gel. Tingginya persentase primer polimorfisme ini menunjukkan bahwa kemampuan primer untuk mengamplifikasi sekuen target. McGregor et al. (2000) menyatakan bahwa polimorfisme merupakan gambaran amplifikasi yang diperoleh dari perbedaan fragmen DNA yang diobservasi dan diskor sebagai ada atau tidaknya perbedaan sekuen sehingga menunjukkan ada tidaknya variasi. Megia dan Djuita (2010) menyatakan bahwa jumlah satu menunjukkan alel homozigot, sedangkan jika berjumlah dua pita, maka menunjukkan alel heterozigot.

Heterozigositas, Uji Statistik untuk Data Kodominan Marka SSR

Untuk menguji data kodominan, peneliti membagi sampel menjadi 3 populasi yaitu populasi progeni, tetua betina, dan tetua jantan untuk memudahkan analisis. Berdasarkan 5 primer SSR yang digunakan menghasilkan beberapa data yang beragam untuk heterozigositas dan uji statistik yang ditunjukkan pada tabel 1 .

Tabel 1. Beberapa parameter keragaman genetik dengan 5 marka SSR pada 3 populasi kedelai terhadap karakter tahan salin

\begin{tabular}{cccccccc}
\hline Populasi & Individu & & $\mathrm{N}$ & $\mathrm{Na}$ & $\mathrm{Ne}$ & $\mathrm{Ho}$ & $\mathrm{He}$ \\
\hline Progeni & 40 & Mean & 20,200 & 10,000 & 7,160 & 0,027 & 0,854 \\
& & $\mathrm{SE}$ & 3,262 & 1,095 & 0,769 & 0,027 & 0,014 \\
\hline Betina & 2 & Mean & 2,000 & 2,000 & 2,000 & 0,000 & 0,500 \\
& & $\mathrm{SE}$ & 0,000 & 0,000 & 0,000 & 0,000 & 0,000 \\
\hline \multirow{2}{*}{ Jantan } & 2 & Mean & 2,000 & 2,000 & 2,000 & 0,000 & 0,500 \\
& & SE & 0,000 & 0,000 & 0,000 & 0,000 & 0,000 \\
\hline Total & 44 & Mean & 8,067 & 4,667 & 3,720 & 0,009 & 0,618 \\
& & SE & 2,504 & 1,063 & 0,692 & 0,009 & 0,045 \\
\hline
\end{tabular}

Ket: $\mathrm{N}=$ Jumlah sampel; $\mathrm{Na}=$ Rata-rata jumlah alel; $\mathrm{Ne}=$ Rata-rata jumlah alel efektif; $\mathrm{Ho}=$ Rata-rata heterozigositas pengamatan; $\mathrm{He}=$ Rata-rata heterozigositas harapan

Hasil analisis jumlah alel efektif (Ne) 7,160 untuk populasi progeni lebih rendah dibandingkan dengan jumlah alel pengamatan $(\mathrm{Na})$ 10,000. Nilai heterozigositas harapan (He) 0,854 pada populasi progeni lebih tinggi daripada nilai heterozigositas pengamatan (Ho) 0,027. Rata-rata keseluruhan heterozigositas pengamatan (Ho) 0,009 lebih rendah dibandingkan rata-rata keseluruhan heterozigositas harapan $(\mathrm{He})$ sebesar 0,618.
Beberapa parameter yang digunakan untuk melihat keragaman genetik dalam suatu populasi antara lain jumlah alel yang teramati $(\mathrm{Na})$, jumlah alel efektif $(\mathrm{Ne})$, persentase lokus polimorfik (PLP) dan heterozigositas harapan $(\mathrm{He})$ (Mondini et al., 2009). Analisis statistik data kodominan dengan 5 primer SSR pada tiga populasi progeni, tetua betina, dan tetua jantan diketahui bahwa rata-rata jumlah alel efektif (Ne) 7,160 untuk populasi 
progeni lebih rendah dibandingkan dengan jumlah alel pengamatan $(\mathrm{Na})$ 10,00. Jumlah alel efektif (Ne) adalah sebuah ukuran dari jumlah alel efektif yang diperoleh dari masing-masing karakter. Nilai ini adalah nilai resiprok atau nilai kebalikan dari homozigositas. Semakin tinggi nilai jumlah alel efektif $(\mathrm{Ne})$ dibanding jumlah alel pengamatan $(\mathrm{Na})$, maka semakin banyak individu yang heterozigot (Solin et al., 2013). Pada penelitian ini nilai jumlah alel efektif $(\mathrm{Ne})$ lebih kecil daripada jumlah alel pengamatan $(\mathrm{Na})$ yang berarti bahwa banyak individu progeni yang homozigot. Rendahnya jumlah alel efektif pada analisis ini diduga materi genetik yang digunakan merupakan populasi tetua persilangan dengan varietas yang sama pada awalnya kemudian dibackcross, yang mengakibatkan memiliki kedekatan genetik dan semakin menurun keragaman genetiknya akibat selfing yang telah dilakukan. Upaya-upaya perbaikan genetik kedelai ini menyebabkan keragaman genetik menyempit, sehingga alel yang diperoleh juga semakin sedikit. Rata-rata jumlah alel efektif $(\mathrm{Ne})$ dengan jumlah alel pengamatan (Na) untuk populasi tetua betina sama dengan tetua jantan yaitu sebesar 2,00. Hal ini diduga kemungkinan nilai frekuensi alel dalam kondisi seimbang. Frankham et al. (2002) menyatakan bahwa jumlah alel efektif akan memiliki jumlah yang sama atau hampir sama dengan jumlah alel pengamatan jika frekuensi alel yang ada dalam kondisi seimbang.

Nilai rata-rata heterozigositas harapan (He) 0,854 pada populasi progeni lebih tinggi dibandingkan rata-rata heterozigositas pengamatan (Ho) sebesar 0,027. Begitu juga nilai rata-rata keseluruhan heterozigositas harapan $(\mathrm{He})$ 0,618 pada seluruh populasi (progeni, tetua betina, dan tetua jantan) lebih tinggi dibandingkan nilai rata-rata keseluruhan heterozigositas pengamatan (Ho) 0,009. Secara umum nilai rata-rata heterozigositas pengamatan lebih rendah daripada nilai rata-rata heterozigositas harapan. Hal ini berarti bahwa setiap karakter memiliki heterozigositas yang rendah. Kriswiyanti (2014) menyatakan bahwa nilai heterozigositas dipengaruhi banyaknya ragam alel dan frekuensi masing-masing alel dalam setiap lokus. Perhitungan nilai heterozigositas berdasarkan kaidah Nei (1987) bahwa nilai heterozigositas berkisar antara 0-1, apabila nilai heterozigositas sama dengan 0 (nol) maka diantara populasi yang diukur memiliki hubungan genetik sangat dekat dan apabila nilai heterozigositas sama dengan 1 (satu) maka diantara populasi yang diukur tidak terdapat hubungan genetik atau pertalian genetik sama sekali. Nilai rata-rata heterozigositas harapan (He) 0,500 pada populasi tetua betina dan tetua jantan dan nilai rata-rata heterozigositas pengamatan (Ho) 0,000 pada populasi tetua betina dan tetua jantan yang berarti kedua populasi memiliki hubungan genetik yang sangat dekat.

KESIMPULAN

Kelima primer SSR

(QS080465, QS1101, QS1112, QS100011, dan Sat_091) yang 
digunakan termasuk primer spesifik, dengan pola pita yang tampak jelas sekitar satu atau dua pita. Persentase primer polimorfik (PLP) dari ketiga populasi ini termasuk tinggi, semua populasi dengan PLP sebesar $100 \%$ terhadap karakter tahan salin. Jumlah alel efektif (Ne) 7,160 untuk populasi progeni lebih rendah dibandingkan dengan jumlah alel pengamatan (Na) 10,000 yang berarti bahwa banyak individu progeni yang homozigot. Nilai heterozigositas harapan (He) 0,854 pada populasi progeni lebih tinggi daripada nilai heterozigositas pengamatan (Ho) 0,027. Rata-rata keseluruhan heterozigositas pengamatan (Ho) 0,009 lebih rendah dibandingkan rata-rata keseluruhan heterozigositas harapan $(\mathrm{He})$ sebesar 0,61. Hal ini berarti bahwa setiap karakter memiliki heterozigositas yang rendah.

\section{DAFTAR PUSTAKA}

Abel, G. H. 1969. Inheritance of the Capacity for Chloride Inclusion and Chloride Exclusion by Soybeans. Crop Science. 697 - 698.

Dasumati. 2003. Seleksi untuk Peningkatan Produksi Biji Kedelai dari Generasi Seleksi 1 (F3) dan Seleksi 2 (F4) Hasil Persilangan Varietas Slamet X Nokonsawon. Bogor : Institut Pertanian Bogor

Frankham, R., J. D. Ballou, dan D. A. Briscoe. 2002. Introduction to Conservation Genetics. United Kingdom : Cambridge University Press
Guan, R., C. Jiangang, J. Jiang, G. Liu, Y. Liu, L. Tian, L. Yu, R. Chang, dan L. Qiu. 2014, "Mapping and Validation of A Dominant Salt Tolerance Gene in The Cultivated Soybean (Glycine max) Variety Tiefeng 8". The Crop Journal. 2 : 258 - 365.

Jianhua, Z., M. B. Mcdonald, dan P. M. Sweeney, 1996. Soybean Cultivar Identification Using RAPD. Seed Science Technology. 24 : 589 - 592.

Krisnawati, A dan M. M. Adie. 2009. Kendali Genetik dan Karakter Penentu Toleransi Kedelai terhadap Salinitas. Iptek Tanaman Pangan. 4 (2) : 222 $-237$.

Kriswiyanti, E. 2014. Karakteristik Ragam Kelapa (Cocos nucifera L.) di Bali Berdasarkan Morfologi, Anatomi dan Molkuler. Denpasar : Universitas Udayana

Maftuchah. 2005. Analisis Variasi Genetik Mangga Menggunakan Penanda RAPD untuk Perbaikan Karakter Kualitas Buah. Laporan Penelitian Unggulan UMM.

McGregor, C. E., C. A. Lambert, M. M. Grylic, J. H. Louw, dan L. Warnich. 2000. A Comparison Assessment of DNA Finger Printing Technique (RAPD, ISSR, AFLP, and SSR) in Tetraploid Potato (Solanum 
tuberosum L.) Germplasma. Euphytica. 113 : 135 - 144.

Megia, R. dan N. R. Djuita. 2010. Deteksi Integritas Genomik Pisang Hasil Iradiasi In Vitro Berdasarkan Penanda Mikrosatelit. Makara, Sains. 14 (22) : 151 - 157.

Mondini, L., A. Noorani, dan M. A. Pagnotta. 2009. Assessing Plant Genetic Diversity by Molecular Tools. Diversity, 1: 19-35.

Nei, M. 1987. Molecular Evolution and Genetics. New York : Columbia University Press

Orozco-Castillo, C., K. J. Chalmers, R. Waugh, dan W. Powell. 1994. Detection of Genetic Diversity and Selective Gene Introgression in Coffee Using RAPD Markers. Journal of Applied Genetics. 87 : 934 90.

Peakall, R. dan Smouse P. E. (2012) GenAlEx 6.5: genetic analysis in Excel. Population genetic software for teaching and research. Bioinformatics. $28: 2537$ - 2539 .

Savitri, E. S. 2010. Pengujian In Vitro Beberapa Varietas Kedelai

(Glycine $\max$ L. Merr.) Toleran Kekeringan Menggunakan Polyethylene Glikol (PEG) 6000 Pada Media Padat dan Cair. El Hayah. 1 (2) : 9 - 13.
Singh R. P., G. Dhania, A. Sharma, dan P.K. Jaiwal. 2007. Biotechnological Approach to Improve Phytoremediation Efficiency for environmental Contaminants. In: Environmental bioremediation technologies. (Eds.: Singh S. N., R. D. Tripathi). Springer.

Solin, N. W. N. M., Sobir, dan N. T. Mathius. 2013. Keragaman Genetik Populasi Tetua Saudara Kandung (Sibs) Kelapa Sawit Dura Deli Berdasarkan Penanda DNA Mikrosatelit. B. Palma. 14 (2) : 100 - 108. 